\title{
METODE PENDIDIKAN PESANTREN GIRI
}

\section{Novita Siswayanti}

Peneliti Puslitbang Lektur, Khazanah Keagamaan dan Manajemen Organisasi

Email: Pipiet1515@gmail.com

\begin{abstract}
Abstrak
Pesantren Giri sebagai pusat pengembangan Islam dan mercusuar pusat pemerintahan Islam yang didirikan oleh Sunan Giri merealisasikan metode pendidikan yang kondusif menjadikan pesantren sebagai pusat pendidikan pelatihan yang progresif dan produktif. Menciptakan kemandirian dan kreatifitas bagi santri dalam berdakwah dan berkarya di masyarakat. Artikel menggunakan metode penelitian deskripsi analisis dengan men deskripsikan metode pendidikan yang diterapkan di Pesantren Giri masa Sunan Giri kemudian dianalisis dan diinterpretasikan. Tujuan penelitian ini mengungkap metode pendidikan yang diterapkan di Pesantren Giri. Adapun metode pendidikan yang diadakan di Pesantren Giri ialah: Metode Wetonan dan Sorogan, diskusi dan tanya jawab, problem solving, dakwah bil-hal, pengamalan, belajar sambil bekerja, sosio darama/pertunjukan, permainan, tembang macapat.
\end{abstract}

Kata kunci: Metode Pendidikan; Pesantren Giri; Sunan Giri

\section{Abstract}

Giri Pesantren as the center of Islamic development and the lighthouse of the Islamicgovernment center founded by Sunan Giri. He realizes a conducive educational method of making pesantren a progressive and productive training education center. Creating independence and creativity for student in da'wah and work in society. The article uses the research method of descriptive analysis by educational methods applied in Pesantren Giri Sunan Giri period then analyzed and interpreted. The purpose of this study reveals the method of education applied in Giri Pesanren. The methods of education held at Pesantren Giri are: Wetonan and Sorogan Methods, discussion and questioning, problem solving, dakwah bilhal, practice, learning while working, socio darama / performances, games, macapat singing.

Keywords: Educational Method; Giri Pesantren; Sunan Giri

Received: 2021-11-22; Accepted: 2021-12-05; Published: 2021-12-20

\section{Pendahuluan}

Metode pendidikan ialah salah satu alat efektif untuk mencapai tujuan pengajaran. Ketika tujuan dirumuskan anak didik memiliki keterampilan tertentu, maka diperguna kan metode yang disesuaikan dengan tujuan pendidikan. Penggunaan metode yang tepat

\begin{tabular}{ll}
\hline How to cite: & Siswayanti,N., Yunani,A., (2021) Akulturasi Budaya dalam Dakwah Maulana Malik Ibrahim, Syntax \\
& Idea, 3(12), https://doi.org/10.36418/syntax-idea.v3i12.1671 \\
E-ISSN: & 2684-883X \\
Published by: & Ridwan Institute
\end{tabular}


dan bervariasi dapat dijadikan sebagai alat motivasi ekstrinsik yang dapat membangkit kan belajar anak didik dalam kegiatan belajar-mengajar (Bahri \& Djumarah, 2002).

Pendidikan Islam atau transmisi Islam pada masa walisanga yang berorientasi pada usaha mendidik anak didik agar bertakwa kepada Tuhan Yang Maha Esa, berkepribadian luhur mulia, memiliki semangat kewiraswastaan dan kemandirian yang tidak menggantungkan diri kepada orang lain telah mengimplementasikan metode pendidikan yang sejalan dengan tujuan pendidikan (Jalaludin, 1990).

Pendidikan Islam masa Walisanga yang sejalan dengan sistem pendidikan pesantren tumbuh dan berkembang di masyarakat; mentoleransi tradisi dan kebiasaan lokal serta memodifikasikannya ke dalam ajaran Islam dengan tetap bersandar pada prinsip-prinsip Islam. Sistem pendidikan yang memadukan tiga unsur pendidikan yang penting,yaitu ibadah, menanamkan keimanan dengan mempelajari ilmu-ilmu keislaman; tablig menyebarkan ilmu dan amal mengamalkan ilmu dapat hidup mandiri di masyarakat, dapat mencari rezeki yang halal dan dapat memberikan bantuan kepada orang lain yang membutuhkan (Amin, 2000).

Sebagai pusat kegiatan pendidikan Islam dan pencetakan kader-kader mubalig walisanga mendirikan masjid sekaligus pesantren. Syeh Maulana Malik Ibrahim spiritual father walisanga orang yang pertama kali mendirikan pesantren di Indonesia. Pesantren masa itu sederhana belum seformal sekarang bentuknya langgar atau musalla yang digunakan untuk belajar ngaji bisa ngaji Al-Qur'an maupun kitab kuning bahkan ada juga yang mengajar ilmu kanoragan (Salam, 1960).

Demikian juga dengan Pesantren Giri yang didirikan oleh Sunan Giri di Giri Kedaton Gresik tumbuh dan berkembang menjadi pesantren sebagai pusat syiar ajaran Islam yang termasyhur di Jawa Timur dan seluruh pelosok Nusantara pada masanya. Pesantren Giri sebagai lembaga kaderisasi yang tidak sekedar mendidik para santri dengan ilmu keislaman saja. Mereka juga ditanamkan dengan spirit perjuangan agama yang kuat diwarnai keselarasan antara zikir, fikir dan ikhtiar (Widodo, 2004).

Pesantrennya tak hanya dipergunakan sebagai tempat pendidikan dalam arti sempit, namun juga sebagai pusat pengembangan masyarakat. Giri Kedaton tumbuh menjadi pusat politik yang penting di Jawa, waktu itu. Bahkan menurut HJ De Graaf lahirnya berbagai kerajaan Islam seperti Demak, Pajang dan Mataram tidak lepas dari peranan Sunan Giri. Seorang raja barulah sah kerajaannya kalau sudah direstui oleh Sunan Giri. Saat Sultan Pajang akan melakukan pemindahan tahta kekuasaan dari Pajang ke Mataram memerlukan legitimasi Sunan Giri.Ketika Raden Patah melepaskan diri dari Majapahit, Sunan Giri bertindak sebagai penasihat dan panglima militer Kesultanan Demak.Demak tak lepas dari pengaruh Sunan Giri.Ia diakui juga sebagai mufti, pemimpin tertinggi keagamaan, se-Tanah Jawa (De Graaf \& Pigeaud, 1985).

Banyak santri yang datang ke Pesantren Giri dari berbagai kalangan baik itu nelayan, saudagar, pedagang atau berasal dari Pulau Jawa dan Pulau pulau Indoensia dari Indonesia Timur seperti Sultan Zainal Abidin dari Ternate, Perdana Jamilu dari Hitu Ambon, Karaeng Matoaya dari Makasar, Raja Banjar dari Banjarmasin, Dato'ri Bandang dark Gowa belajar dengan Sunan Giri di Pesantren Giri. Para alumni dan 
keluarga pesantren Giri setelah kembali ke daerahnya menjadi mubalig yang tangguh dalam menyiarkan agama Islam. Mereka berdakwah mendirikan pesantren dan pengajian yang awalnya kecil, lama kelamaan bertambah besar dan terkenal. (Mustakim, 2020).

Pesantren Giri sebagai lembaga pendidikan dan kemasyarakatan mentransfer fatwa syariat Islam dan menginternalisasikan nilai-nilai Islam secara praktis sesuai dengan sosial kemasyarakatan dan kebutuhan peserta didik, sehingga mereka dapat hidup mandiri dan menerapkan ilmunya di masyarakat. Pesantren Giri meng implementasikan berbagai metode pendidikan secara variatif dan menggembirakan yang dapat menstimulus dan memotivasi minat dan kreatifitas belajar peserta didik. Pesantren Giri mentransfer fatwa syariat keagamaan secara ceramah atau diskusi, melatih peserta didiknya untuk mandiri melalui keterampilan berdagang, pertukangan, perikanan, ataupun menyampaikan pesan-pesan politiknya melalui tembang atau wayang sesuai dengan tradisi masyarakat (Gani, 2012).

Sunan Giri menggunakan media dan sarana budaya yang mentradisi dan disukai masyarakat. Sunan Giri menciptakan lagu-lagu tembang permainan dolanan yang mengandung ajaran dan jiwa keislaman, seperti jelungan, cublak-cublak suweng, ilirilir, bendi gerit, gula ganti yang diiringi dengan irama musik gamelan Jawa meneruskan sistem mandala sebagai institusi pendidikan yang berkembang menjadi pesantren. Lagulagu itu selain mudah dipahami dan dimainkan oleh anak-anak dan remaja juga sangat digemari rakyat karena berisi ajaran yang bertingkat tinggi (Mustakin, 2005).

Pesantren Giri yang didirikan oleh Sunan Giri pada masa awal berdirinya Giri Kedaton (1481 M) pusat pengembangan Islam para walisanga. Pesantren Giri diresmikan tepat pada perayaan Maulid Nabi Muhammad saw. dengan ditandai shalat Jumat berjamaah tepat pada tahun 1487 Masehi. Pesantren Giri sebagai lembaga pendidikan tertua di tanah Jawa telah menerapkan metode pendidikan yang bervariasi dalam menyampaikan ilmu-ilmunya kepada peserta didik (Mustakin, 2005). Kajian tentang Pesantren Giri sangatlah menarik untuk dikaji secara lebih detail tentang metode pendidikan apa sajakah yang diterapkan di Pesantren Giri dalam merangsang motivasi belajar peserta didik

Masalah Penelitian yang dikaji terkait dengan metode pendidikan pesantren Giri meliputi apa sajakah metode pendidikan yang diterapkan di Pesantren Giri dan bagaimanakah metode pendidikan yang diterapkan di Pesantren Giri.

Tujuan Penelitian.Berdasarkan pada pokok permasalahan sebagaimana tersebut, maka penelitian bertujuan: untuk mengungkapkan berbagai macam dan model metode pendidikan yang diterapkan di Pesantren Giri; Artikel yang bersumber dari penelitian ini diharapkan dapat mendeskripsikan historis dan peran sosial Metode Pendidikan yang diterapkan Pesantren Giri, sehingga dapat menambah khazanah keagamaan Nusantara, digali nilai-nilai kearifan lokal, dikonservasi dan direorientasi metode pendidikan yang dapat diterapkan di pesantren kekinian. 
Kajian tentang Metode Pendidikan Pesantren Giri ini akan mengungkapkan dan menjelaskan beragam metode pendidikan yang diterapkan di Pesantren Giri pada masa Sunan Giri. Pesantren Giri memiliki peranan penting dalam penyebaran Islam di Jawa.

\section{Metode Penelitian}

Metodologi Penelitian Penelitian Metode Pendidikan Pesantren Giri menggunakan metode penelitian analisis deskriptif dengan mendeskripsikan beragam metode pendidikan Pesantren Giri pada masa Sunan Giri kemudian dilakukan analisis dan penafsiran. Sedangkan pendekatan yang digunakan dalam penelitian ini adalah historis dan pendidikan. Pendekatan historis dilakukan untuk men $\neg$ deskripsi $\neg$ kan latar belakang sejarah keberadaan Pesantren Giri dan sejarah sosial pendiriannya. Sedangkan pendekatan pendidikan untuk mengungkapkan berbagai metode pendidikan yang diterapkan dalam Pesantren Giri dan tinggalannya berupa hasil kerajinan dan kesenian baik macapat maupun pewayangan masih diaplikasikan dan dimanfaatkan oleh masyarakat Gresik, dengan tujuan untuk mengungkap kehidupan manusia masa lalu melalui kajian atas tinggalan-tinggalan kebendaan maupun tradisi dan budaya.

Berdasarkan kedua pendekatan tersebut, metode pengumpulan data yang digunakan dalam penelitian ini adalah: interview, observasi, dan kajian pustaka meliputi kajian pendidikan, etnografi, historis, antropologis. Sedangkan sumber data primer diperoleh langsung dari responden atau informan, pemuka adat dan sejarawan, imam dan pengurus Giri Kedaton, dan Dinas Pariwisata dan Kebudayaan. Sementara data sekunder diperoleh dari Perpustakaan, Badan Pelestarian Budaya, Badan Pusat Statistik dan Pusat Informasi Lainnya.

Kajian Pustaka. Landasan teori yang digunakan dalam penelitian ini berasal dari kajian pustaka. Kajian pustaka digunakan untuk memperoleh bahan-bahan yang berkaitan dengan Metode Pendidikan Pesantren Giri. Kajian pustaka juga bermanfaat dalam memberikan sejumlah informasi dan teori serta pemahaman yang menyangkut topik kajian Adapun beberapa sumber literatur yang digunakan antara lain:

Referensi ringkas, padat, yang sudah diterjemahkan oleh Soekarman dalam Babad Gresik serta buku karya Erfan berjudul Sejarah Kehidupan Sunan Giri merupakan referensi utama yang berisikan tentang sejarah kelahiran, peran dam silsilah Sunan Giri di tanah Jawa. Selain itu buku berjudul Sunan Giri karya Umar Hasyim dan novel Giri Raja dan Sunan Besar yang Terlupakan karya Yudhi menceritakan dan men deskripsikan secara naratif dan prosa tentang siapa dan bagaimana kehidupan Sunan Giri sejak masa lahir, pendidikan, perannya dalam pengasuh dan pemimpin pesantren serta kepemimpinan Sunan Giri sebagai Prabu Satmata dalam memimpin Kedaton Giri dan mufti walisongo Raden Fatah Kerajaan Demak di Tanah Jawa.

Buku hasil penelitian Lembaga Riset Islam Pesantren Luhur Malang berjudul Sejarah Perjuangan dan Dakwah Islamiyah Sunan Giri yang sebelumnya memaparkan asal mula agama Islam masuk di Jawa Timur,penyebaran Islam pada Masa Walisongo ini sangat komprehensif memberikan gambaran tentang biografi dan Dakwah Islamiyah Sunan Giri. Kelahiran dan Silsilah Sunan Giri, pendidikan dan masa kecil Sunan Giri, 
peranan Sunan Giri sebagai pendidik dan penyebar Islam, Peranan Pesantren di Kedaton Giri dalam Dakwah Islamiah, Media dan daerah dakwah Sunan Giri, Pengaruh dakwah dan penyiaran Sunan Giri serta karomah dan peninggalan Sunan Giri.

Buku-buku terkait pesantren diantaranya: Buku Tradisi Pesantren Zamakhsyari Dhofier mengungkapkan secara deskriptif dan jelas seluk-beluk tradisi pesantren mulai dari latar belakang sejarah berdirinya pesantren, strategi pengajaran di pesantren, elemen-elemen yang berperan dalam keberlangsungan pesantren sebagai pusat pendidikan, pusat dakwah serta pusat informasi agent of culture aset sosial dan budaya bagi kemajuan pembangunan masyarakat, gambaran aktifitas kehidupan sehari-hari santri di pesantren, serta peran kiai sebagai figur pemimpin dalam mensinergikan dua entitas tradisi dan modernitas sebagai upaya membangun peradaban dan kemajuan bangsa.

Suismanto dalam bukunya Menelusuri Jejak Pesantren, menjelaskan peran dan fungsi pesantren sebagai pusat dakwah dan pengembangan masyarakat, pusat belajar, pusat informasi, pusat latihan keterampilan dan bengkel kerja. Sehingga santri alumni pesantren mempunyai kecakapan, keahlian, kreatifitas dan kemandirian dalam mengaplikasikan bakat, minat dan ilmunya yang bermanfaat bagi dirinya sendiri maupun kemajuan pembangunan masyarakat. Selain itu tulisan Marwan Saridjo Sejarah Pondok Pesantren di Indonesia menuliskan yang merupakan kumpulan artikel memmberikan gambaran tentang sejarah pertumbuhan dan perkembangan pesantren di Indonesia mulai zaman permulaan Islam, masa walisongo, masa penjajahan sampai masa kini tahun 80-an.

\section{Hasil dan Pembahasan}

\section{Pesantren Giri}

Pesantren Giri didirikan oleh Sunan Giri pada tahun Jawa ardi luhur kinanti jalma 1407 Saka (1485 Masehi). Sunan Giri salah seorang walisanga yang memiliki peranan penting dalam penyebaran Islam di Tanah Jawa. Sunan Giri merupakan tokoh kharismatik yang memiliki basis santri intelektual, sehingga ia diundang oleh Raden Patah Demak untuk ikut mengokohkan secara resmi berdirinya Kerajaan Islam Demak di bumi Nusantara. Sunan Giri diangkat sebagai mufti pemimpin tertinggi keagamaan se-Tanah Jawa yang bergelar Prabu Satmata (Hasyim, 1979).

Sunan Giri yang memiliki nama kecil Raden Paku lahir di Blambangan tahun 1442 M. Ayahnya Syeh Maulana Ishak ulama dari tanah Arab yang tinggal di Pasai Aceh dan ibunya Dewi Sekardadu anak dari Prabu Menak Sembuyu,penguasa wilayah Blambangan pada masa-masa akhir Majapahit. Sunan Giri belajar agama Islam dengan Sunan Ampel, kemudian melanjutkannya ke Pasai bersama Sunan Bonang untuk belajar agama kepada ayahnya Syeh Maulana Ishak. Sampai akhirnya kembali lagi ke Jawa membangun pesantren dan menyebarkan agama Islam di Jawa. (Soekarman, 1990).

Sunan Giri mendirikan pesantren atas perintah ayahandanya sekaligus gurunya untuk pulang ke Tanah Jawa menyiarkan Islam sepanjang pantai selatan Jawa. 
Begitu selesai belajar ilmu ma'rifatullah dengan ayahandanya Maulana Ishak Sunan Giri diberikan jubah longgar, destar dan topi kebesaran (makutho). Ayahnya juga memberi kan segumpal tanah dari Mekah, agar dicocokkan bentuk dan struktur tanahnya dengan tanah yang berada di Barat Daya Gresik. Maka jika sudah menemukan tanah tersebut jangan pergi haji,tetapi buatlah terang terlebih dahulu tanah Jawa yang saat ini masih gelap (Soekarman, 1990).

Setelah mencari ke berbagai tempat di wilayah Gresik, akhirnya Sunan Giri menemukan lokasi yang sesuai dengan tanah pemberian ayahnya yaitu berada di atas gunung. Menurut kepercayaan pra Islam gunung adalah tempat keramat yang sakral tempat bersemayamnya arwah nenek moyang Dewa Ciwa atau Dewa Gunung. Awalnya tempat ini dijadikan sebagai pusat penyebaran agama selain Islam yang diberi nama Tapanawa, kemudian oleh Sunan Giri dikuasai dan diganti dengan tradisi yang Islami. Hubungan sex dan minum-minuman keras yang telah menjadi kultur atau budaya sebelum Islam, saat kedatangan Sunan Giri dihapuskan, dan kembali pada Al-Qur'an dan Hadis (Kasdi, 2005).

Kemudian tepat di Bukit Giri pada tahun tingali luhur dadi ratu (1403 Saka) atau 1481 Masehi Sunan Giri mendirikan pemukiman penduduk, membuat telaga pegat, masjid, dan pesantren tempat belajar para santri. Pesantren Giri Kedaton terletak di atas bukit Desa Sidomukti. Pesantren Giri diresmikan tepat pada perayaan Maulid Nabi Muhammad saw. dengan ditandai shalat Jumat berjamaah tepat pada tahun 1487 Masehi. Peresmian Pesantren Giri dihadiri oleh Raden Fatah Demak dan mengangkat Sunan Giri sebagai Prabu Satmata (Yudhi, 2011).

Pesantren Giri merupakan pusat ajaran Tauhid dan Fiqih yang mengajarkan AlQuran dan Sunah Rasul. Sunan Giri tidak mau berkompromi dengan adat istiadat yang dianggapnya merusak kemurnian Islam. Oleh karena itu Sunan Giri dianggap pemimpin kaum "Putihan" bersama Sunan Ampel dan Sunan Drajat. Semasa kecilnya Sunan Giri menuntut ilmu tafsir, hadis, fikih, dan ilmu nahwu-saraf dengan Sunan Ampel. Sunan Giri sangat mendalami ilmu tauhid dan ilmu fikih maka ia sangat pandai dalam menentukan hukum sehingga ia disebut Abdul Fakih. Ia tidak kenal kompromi dalam masalah ibadah dengan agama dan kepercayaan selain Islam

Pesantren Giri tumbuh dan berkembang sebagai pusat pengembangan Islam dan mercusuar pusat pemerintahan Islam. Santrinya berdatangan dari berbagai daerah; Jawa, Maluku, Sulawesi, Sumbawa maupun Kalimantan. Santrinya ada yang mukim menetap dalam pesantren dan santri kalong tidak tinggal di pesantren kecuali waktu-waktu belajar dan mengaji. Pada saat malam tiba santri kalong datang menuntut ilmu ke pesantren, sedangkan saat pagi dan siang hari mereka melakukan aktifitas sehari-hari berdagang atau bercocok tanam (Zainuddin et al., 2016).

Dalam perkembangannya, Pesantren Giri menjadi sebuah masyarakat belajar yang berfungsi sebagai pusat belajar tafaqquh fiddin bagi para santri memperoleh pendidikan dan pengajaran, pusat informasi agent of culture aset sosial dan budaya bagi kemajuan pembangunan masyarakat, pusat latihan keterampilan dan bengkel kerja bagi santri dan masyarakat untuk terampil di bidang pertukangan, 
perbengkelan, pertanian, maunpun perdagangan dan pusat dakwah pengembangan masyarakat memberikan latihan dan pelayanan terpadu bagi kemajuan masyarakat (Suis, 2004).

\section{Metode Pendidikan Pesantren Giri}

Pendidikan yang ada di pesantren ialah pendidikan kemasyarakatan. Segenap santri berlatih memperhatikan dan mengerjakan hal-hal yang nanti akan dialami di masyarakat. Segala sesuatu diselenggarakan dengan mengingat hal-hal yang akan dijumpai oleh santri di masyarakat. Santri dididik kesederhanaan dan keikhlasan dalam hidupnya yang akan menumbuhkan pribadi yang berani, percaya diri, jujur, bertanggung jawab kepada diri sendiri dan masyarakat (Saridjo, Shaleh, \& Syarif, 1979).

Untuk itu Pesantren Giri sebagai lembaga pendidikan kemasyarakatan, kiai dan santrinya bukan hanya berpartisipasi dengan masyarakat, tetapi juga berintegrasi dengan kehidupan dan kebutuhan masyarakat. Pesantren Giri menjadi sebuah masyarakat belajar (learning community)yang berfungsi sebagai pusat dakwah dan pengembangan masyarakat, pusat belajar, pusat informasi, pusat latihan keterampilan dan bengkel kerja. Dengan demikian sumber daya setempat, kecakapan dan keterampilan lokal, serta kreatifitas baik bidang kerajinan maupun kebudayaan masyarakat terus dikembangkan dan diperkaya. Kiai sebagai pengasuh dengan sistem among membimbing santri dan masyarakat sekitar untuk saling belajar, saling mengasihi dan saling membantu (Wawancara dengan Mohamad Ma'arif Pengurus Masjid Sunan Giri Gresik, 2016).

Oleh karena itu dalam rangka mentransfer dan menginternalisasikan nilai-nilai Islam, Sunan Giri menerapkan metode pendidikan yang mengakulturasikan adat istiadat lokal dengan nilai-nilai Islam. Guru berperan dalam merealisasikan metode pendidikan yang kondusif menciptakan kegiatan belajar belajar yang kondusif sehingga menjadikan pesantren sebagai pusat pendidikan dan latihan yang progresif dan produktif menciptakan kemandirian dan kreatifitas bagi santri dalam berdakwah dan berkarya di masyarakat (Wawancara dengan Mustakim, Pemerhati Sejarah Gresik, 2016).

Adapun metode pendidikan Pesantren Giri adalah:

\section{1) Metode Wetonan dan Sorogan}

Pesantren Giri sebagai lembaga pendidikan yang tumbuh dan berkembang di tengah- tengah masyarakat menyelenggarakan kegiatan pembelajaran secara non klasikal sorogan bandongan, dan wetonan yang diikuti oleh santri kalong maupun santri yang mondok di Pesantren Giri. Secara wetonan santri kalong yang tidak mondok di Pesantren Giri datang berduyun-duyun pada waktu tertentu sebelum dan atau sesudah shalat fardhu untuk mengikuti kajian keagamaan di Pesantren Giri.Para guru mengajar santri-santrinya berdasarkan kitab-kitab yang ditulis dalam Bahasa Arab oleh ulama besar sejak abad pertengahan (Salam, 1960). 
Sunan Giri memperoleh ilmu dari gurunya Sunan Ampel dan ayahandanya Syeh Maulana Ishak bermacam ilmu fikih, tafsir hadis, nahwu dan saraf, tasawuf/ marifatullah. Di Pesantren Giri Sunan Giri mengajarkan kepada santrinya ilmuilmu keagamaan yang dipelajarinya dari gurunya dengan metode sorogan dan bandongan. Guru membaca dan menerjemahkan kitab-kitab Islam klasik disertai dengan interpretasi pandangan pribadinya baik secara bahasa maupun isi kepada santri. Santri menyimak, menandai dan memberi catatan pada kitab yang dibahas. Secara sorogan santri menghadap kepada guru dan membacakan kembali isi kitabnya (Saridjo et al., 1979).

Salah satu kitab yang menjadi referensi dan rujukan bagi santri di Pesantren Giri adalah Kitab Sittin. Kitab sittin mengandung hukum hukum ibadah terutama masalah sembahyang praktis berpegang teguh kepada Al-Qur'an dan Hadis mengagungkan asma Allah memberikan praktek amalan. Mengajarkan tata cara beribadah dengan panduan kitab sittin unsir insur kefitrahan manusia dalam islamcara berpikir cara merasakan berilmu beramal sholeh dan berbudi mulai dengan ajaran agama Islam yang berpangkal kepada dua kalimat syahadat pengajaran dan pendidikan praktis (Lembaga Riset Islam Pesantren Luhur Malang dan Panitia Penelitian Dan Pemugaran Sunan Giri, 2014).

Metode sorogan dan bandongan sangat efektif menciptakan suasana dinamis dan kreatif bagi para santri untuk mengeksplorasi ilmunya. Metode sorogan dalam dunia modern dapat dipersamakan dengan istilah tutorship atau mentorship sebab ada kesempatan untuk tanya jawab secara langsung antara guru dengan santri. Setiap tema yang dibahas ada penjelasan dari guru dan terjadinya tanya jawab dan komunikasi dua arah-tiga arah yang merangsang santri untuk melatih serta mengembangkan daya pikir dan daya ingat nya. Santri memiliki keberanian dan keterampilan untuk mengemukakan pendapat berdasarkan pengalaman dan pemikiran yang dimilikinya. Selain itu dengan metode sorogan dan bandongan juga mengembangkan kemandirian, disiplin, dan tanggumg jawab terhadap kemajuan dan penguasaan ilmu yang dipelajarinya.

\section{2) Metode Diskusi dan Tanya Jawab}

Pesantren merupakan model di mana guru adalah religius figur tidak hanya berperan sebagai pengajar, namun memiliki multiperan sebagai fasilitator, dinamisator, inovator dan komunikator.Guru adalah agent of culture yang mampu meng interpretasikan pesan Ilahi dan risalah profertik serta mampu mengidentifikasikan kebutuhan, permasalahan dan harapan masyarakat. Untuk itu dalam dinamika pesantren, kiai dan santri sering dihadapkan pada berbagai masalah, baik yang berkaitan dengan mata pelajaran maupun yang menyangkut hubungan sosial (Dhofier Zamakhsyari, 2011).

Pemecahan masalah pembelajaran dapat dilakukan melalui berbagai cara, melalui diskusi kelas, tanya jawab antara kiai dengan santri, penemuan maupun inkuiri. Dengan berdiskusi dan tanya jawab maka akan mendorong anak didik untuk berani berpendapat dan berargumentasi. Merangsang kreatifitas santri untuk 
mengungkapkan ide, gagasan dan terobosan baru dalam pemecahan suatu masalah. Dengan berdiskusi akan melatih kebebasan santri untuk berani mengambil keputusan dalam memilih jalan hidupnya sendiri tanpa melepaskan penghormatan pada yang lainnya dengan pengertian sesuai dengan batasan hukum Islam.

Pesantren Giri sebagai lembaga pendidikan dan kemasyarakatan yang memberikan solusi keagamaan maupun sosial kemasyarakatan menyelenggarakan metode diskusi dan tanya jawab dalam menyelesaikan berbagai persoalan masyarakat. Pesantren Giri sebagai tempat permusyawaratan dan pertemuan para walisanga dalam menyatukan pendapat. Diantara walisanga ada dua kelompok dalam berdakwah yaitu kaum putihan dan kaum abangan. Kaum putihan diketuai oleh Sunan Ampel, Sunan Drajat, dan Sunan Giri yang berprinsip pada pemurnian agama dari khurafat sedangkan kaum abangan diketuai oleh Sunan Kalijaga, Sunan Kudus dan Sunan Bonang yang mengakulturasikan budaya lokal dengan nilai Islam (Syamlawi, Pudjosumedi, \& Mahbub, 1983).

Oleh karena itu untuk menemukan kesepakatan antara kedua kaum diadakan diskusi secara mufakat untuk menentukan garis perjuangan baik di bidang agama maupun pemerintahan. untuk mencapai mufakat. Dalam musyawarah disepakati Sunan Giri diangkat sebagai mufti penasehat para wali se-Jawa dan Sunan Kalijaga sebagai pemimpin politik dan pemerintahan dengan Giri Kedaton sebagai pusat penyebaran Islam sekaligus kerajaan rohani (Syamlawi et al., 1983).

Sunan Giri sebagai sesepuh tempat meminta nasihat dan pembimbing spiritual. Bahkan dalam pemberitaan asing Sunan Giri adalah Paus Islam Jawa dimana seorang raja tidak dinobatkan sebagai raja jika tidak ada penobatan dari Sunan Giri. Sunan Giri ber pengetahuan luas dalam hukum Islam oleh Sultan Demak diserahi tugas untuk memutus kan berbagai permasalahan dan diselesaikan. secara permusyawatan. Misal saat terjadi perselisihan faham wujudiah (manunggaling kawula gusti) yang dianut oleh Syeh Siti Jenar di satu pihak lain menentang paham itu, Sunan Giri berusaha mendamaikannya (Kasdi, 2005).

\section{3) Metode Problem Solving}

Pesantren Giri melatih anak didiknya agar mampu memecahkan masalah secara terampil, kreatif, mandiri dalam menghadapi segala permasalahan di dalam kehidupan baik pribadi, keluarga, maupun sosial (Soekarman, 1990). Dengan metode problem solving dapat menumbuh kan rasa persaudaraan dan kerukunan hidup dalam suasana gotong-royong dan tolong-menolong meringankan beban bersama. Sehingga anak didik memiliki kesadaran untuk peduli dan cinta kepada kepentingan masyarakat, mendahului kepentingan bersama di atas kepentingan pribadi. Memikirkan hajat kebahagiaan atau kesejahteraan umat manusia; sebaikbaik manusia yang bermanfaat bagi sesamanya.

Pada musim kering pesantren Giri kekurangan air, santri dan masyarakat Giri Kedaton sulit mendapatkan air. Kemudian Sunan Giri berdiskusi mengajak santrinya untuk memecahkan masalah secara mufakat dengan menggali sebidang 
tanah agar muncul air yang mengalir ke Kedaton Giri. Tempat penampungan air hingga sekarang masih berfungsi dan digunakan untuk keperluan bersama dan dikenal sebagai 'Telaga Pegat' Saat itulah suatu keajaiban terjadi ketika kegiatan pengalian telaga sedang berlangsung, Raden Paku menyediakan nasi yang dimasak dalam periuk (kendil) yang tiada habisnya meskipun dimakan berpuluhpuluh orang, asalkan isi periuk (nasi) tidak ditumpahkan dan periuknya dihadapkan ke bawah. Pekerjaan tersebut selesai pada tahun 1408 S/1486 M. Ditandai dengan CondroSengkolo "Sumedya resik her wulu." (Soekarman, 1990).

\section{4) Metode Dakwah bil-Hal}

Pesantren Giri sebagai lembaga pendidikan dan kemasyarakatan tidak semata-mata mentransfer ilmu kepada anak didiknya, tetapi juga menginternalisasikan nilai-nilai Islam ke dalam sikap dan perilaku yang mulia. Seorang guru menyampaikan ilmunya guna memperbaiki dan membentuk akhlak mulia yang dipandang baik menurut nilai-nilai Islam. Sunan Giri mengajar santrinya dengan metode dakwah bil-hal mem berikan keteladanan dan suri tauladan yang baik dalam perkataan maupun perbuatan. Dengan keteladanan dapat menimbulkan keakraban dan persahabatan batiniah yang kental antara guru dengan santri dan santri dengan santri (Wawancara dengan Mukhtar Djamil Tokoh Agama Gresik, 2016).

Melalui kegiatan sosial kemasyarakatan seperti selamatan, tasyakuran, upacara Sunan Giri berdakwah bil-hal menginternalisasikan nilai-nilai keislaman dengan kesantunan sikap dan ucapan lemah lembut, sehingga masyarakat bersedia menerima ajaran Islam dengan kesadaran dan kemauan sendiri dalam suasana menyenangkan, penuh keakraban dan tanpa paksaan (Wawancara dengan Oemar Zainudin Budayawan Gresik, 2016).

Dalam proses pendidikan Sunan Giri mengajarkan kepada santrinya agar dalam meraih cita-cita luhur selalu ikhlas karena Allah, mampu menekan gelora hawa nafsu mengabaikan segala bentuk rintangan, dan disiplin dalam waktu. Selain itu Sunan Giri juga membimbing dan menuntun anak didiknya agar menjalin hubungan yang baik dengan guru,santun dan menghormati guru, bertutur kata yang baik,mengikuti petunjuk, tidak membantah dan berdusta kepadanya, tidak mencela semua ajaran pendidik, tidak segan bertanya tentang masalah yang belum diketahui dan tidak melupakan pendidik terdahulu bila akan menambah ilmu dengan guru lain Pribadi pendidik berakhlak mulai yang baik (Lembaga Riset Islam Pesantren Luhur Malang dan Panitia Penelitian Dan Pemugaran Sunan Giri, 2014).

Melalui metode dakwah bil-hal, Sunan Giri mencontohkan akhlak dan pribadi yang mulia, sehingga ia disegani dan dimuliakan oleh santrinya, masyarakat maupun lawan-lawannya. Sunan Giri selalu membuat senang hati orang lain, walau dalam suasana riang selalu ingat dan waspada. Ia menunjukkan pola hidup sederhana tidak berlebih-lebihan dalam kehidupan materiil sehari-hari. Sunan Giri menasihati santrinya agar memberi ilmu supaya orang menjadi 
pandai,menyejahterakan kehidupan orang yang miskin, mengajari kesusialaan kepada orang yang tidak kenal malu dan memberi perlindungan bagi orang yang menderita (Mustakim, 2020).

\section{5) Metode Pengamalan}

Ilmu akan semakin bertambah dan dipahami jika dilanjutkan pada praktek dan pengamalan. Pengamalan merupakan pendekatan yang efektif melahirkan keterampilan, mengokohkan keberadaan ilmu di dalam kalbu dan meneguhkannya dalam ingatan. Pesantren Giri memberikan pelatihan dan keterampilan dalam berbagai bidang kehidupan yang langsung dipraktekkan kepada santrinya sehingga nantinya dapat hidup terampil dan mandiri dalam memenuhi keperluan hidupnya sendiri maupun masyarakat (Syarifudin, 2020).

Para santri mengikuti program latihan dan keterampilan terpadu melalui pengembangan motivasi dan manajemen usaha. Pesantren Giri sebagai bengkel kerja dengan memberikan kesempatan latihan dan praktek langsung kepada santrinya dalam hal pertukangan, perbengkelan, elektronika, pertanian, perdagangan dan sebagainya. Misalkan saat mendirikan pesantren, santri memperoleh pengalaman sendiri ikut serta dalam pertukangan, penataan jalan, aliran listrik maupun saluran air. Hingga akhirnya Kedaton Giri menjadi lingkungan pesantren, pemukiman penduduk, mushalla dan telaga pegat untuk pengairan di atas bukit (Sudihartono, 2020).

\section{6) Metode Belajar sambil Bekerja}

Salah satu karakteristik pesantren adalah kemandirian. Pesantren Giri mendidik santrinya agar memiliki jiwa kewiraswastaan, bukan hanya mampu untuk mandiri, tetapi memiliki keterampilan dan keahlian untuk menciptakan lapangan pekerjaan bagi orang lain. Sunan Giri berbisnis dengan berbagai komunitas hingga keluar Pulau Jawa Banjarmasin dan Halmahera. Santri ikut mengatur dagangannya di pasar sehingga pembeli dapat dengan mudah memilih dan mencari barang dagangannya. Barang dagangan pun dijual dengan harga yang wajar dan terjangkau sehingga pembeli langsung membelinya tanpa menawar terlebih dahulu. Kedaton Giri pun mencapai kemajuan di bidang ekonomi dengan adanya perkampungan sarung khas gresik dan kampung saudagar Pakelingan Pecinan Kampung Arab (Mustakim, 2020).

Sunan Giri sejak muda sudah ikut ibu angkatnya Nyai Gede Pinatih berniaga ke Pulau Banjar dengan membawa barang dagangan hasil bumi tanah Jawa kain batik dan gula. Terkadang Sunan Giri memberikan barang dagangannya dengan cuma-cuma kepada fakir miskin dan barang dijualnya dengan harga yang murah. Harta benda tersebut diniatkan sedekah berbagi kepada kaum duafa dan zakat membersihkan harta. Ia membebaskan pembelian barang dagangannya dan menghalalkannya kepada kaum duafa, sehingga ia mendapat teguran dari ibundanya. Kemudian barang dagangan yang kosong diisi dengan batu dan pasir atas izin Allah berubah menjadi rotan dan lilin. Sejak itu ibundanya gemar 
bersedekah pada para murid juga membutuhkan bantuan dan dikirmnya kepada Ngampel Surabaya (Erfan).

Atas pengalamannya dalam berdagang Sunan Giri menanamkan sendi-sendi berbisnis kepada santrinya. Berdagang dengan santun dan lemah lembut, menawarkan barang dagangannya tidak semata-mata mencari keuntungan tetapi sambil berdakwah amar maruf nahi munkar. Berdagang dengan jujur dan mengungkapkan keunggulan ataupun kekurangan suatu barang.Sunan Giri juga menanamkan nilai-nilai kedermawanan yang jarang dimiliki oleh pebisnis saat itu juga masa kini. Ia menginginkan pebisnis di Grissee berjiwa dermawan. Bersedekah memberikan sebagian harta yang dimilikinya kepada kaum duafa dan berzakat membersihkan harta. Ia menerapkan ajaran mulia sukses berbisnis dan punya kepedulian sosial yang tinggi (Erfan).

\section{7) Metode Sosio Drama/Pertunjukan}

Metode sosio drama sebagai salah satu metode bercerita dengan menampilkan berbagai kisah, alur cerita, penokohan yang dilengkapi dengan alat peraga. Dengan pertunjukan sosio drama dapat menanamkan pendidikan moral dan pesan-pesan agama tanpa menggurui, menumbuhkan rasa humor, memperluas wawasan dan pengetahuan dari alur cerita dan penokohan yang diperankan. (Shaleh, 2000).

Pentas wayang adalah refleksi simbolis hubungan sosial vertikal kepada Sang Maha Kuasa dan horisontal kepada sesama manusia maupun makhluknya di muka bumi. Sang dalang menyampaikan kisah dan cerita pewayangan yang dramatis serta diberi jiwa agama.Sang dalang berkisah secara atraktif dengan artikulasi kata yang jelas dan intonasi suara yang memikat sesuai dengan tokoh yang perankan. Dengan kisah pewayangan yang ditampilkan terbangun pengalaman emosional yang mendalam, mengembangkan daya imajinasi, dan memberikan kesenangan. Sunan Kalijaga beserta sunan lainnya mentransfer nilainilai Islam melalui pewayangan dan cerita pewayangan dengan corak kebudayaan Jawa (Rahimsyah, 2013).

Dalam pengajaran dan penyiaran dakwah Islam Pesantren Giri menpergunakan metode sosiodrama dalam bentuk pementasan wayang kulit yang menarik, menghibur, dan tema yang mentradisi di lingkungan para santri dan masyarakat Giri Kedaton. Sunan Giri menciptakan wayang gedog atau wayang topeng dan ada juga wayang krucil atau wayang klitik yang bentuknya kecil terbuat dari kayu. Sunan Giri juga menciptakan wayang kancil dengan peraga wayang gedog bentuk kancil sebagai sarana untuk menyebarkan ajaran Islam di Jawa dan Lombok. Seni ini sempat menghilang, tapi sekarang dihidupkan kembali. Pertunjukan wayang dipentaskan dengan tema yang bervariasi dan dalam berbagai bahasa disesuaikan dengan watak, sifat, dan perilaku tokoh-tokoh yang diwayangkan.Cerita pewayangan menggambarkan etnik keislaman, norma dan kesusilaan dalam hidup sepanjang tuntunan dan ajaran Islam Pementasan wayang 
sebagai media untuk mendidik moral dan watak santrinya sesuai dengan nilai-nilai dan ajaran Islam (Salam, 1960).

\section{8) Metode Tembang-Macapat}

Sebagai lembaga pendidikan kemasyarakatan sekaligus lembaga dakwah yang menyebarkan dan menyiarkan Islam, Pesantren Giri menyampaikan pesan dakwahnya dengan metode tembang-macapat atau melantunkan syair-syair Islami. Tembang berarti karangan bunga yang beraroma harum wangi. Wali menyarankan agar berdakwah Islam dilakukan dengan menaburkan bunga yang harum, menyenangkan, menggembirakan dan enak didengar dan dihindari dakwah secara polos, kasar, memaki maki atau menyindir yang melukai hati (Sono, 2008).

Mengajar dengan metode tembang atau macapat berisikan syair-syair bernapaskan nilai-nilai Islam yang menyenangkan hati, secara tidak langsung pesan Islam mudah diingat, diterima, dan diaplikasikan dalam kehidupan seharihari. Sunan Giri menciptakan tembang kinanthi sebagai metode mengajar yang artinya dikanthi, digandheng atau ditemani. Melalui tembang kinanthi Sunan Giri mengajak dan menemani orang yang masih buta dari petunjuk Allah untuk dituntun menuju kepada hidup beragama. Mengajak dan mendekati teman baru dengan cara damai, bijaksana, dan berbudi pekerti luhur (Slamet, Ahmad).

Sunan Giri menyenandungkan tembang-macapat kinanthi diiringi dengan alat musik terbang kedung, tambur, seruling, harmonika dan ketipung Seperti halnya dakwah Islam yang dilakukan oleh walisanga tembang macapat yang dilantunkan berisikan syair-syair pujian kepada Allah, kisah asal mula terjadinya alam semesta, kejadian manusia, cerita kehidupan Nabi Muhammad dan perjalanan dakwahnya dalam menyiarkan Islam (Gani, 2012).

Salah satu tembang kinanthi karya Sunan Giri yang dinyanyikan dalam permainan dolanan anak pada padang bulan purnama bunyinya: Padang-padang bulan, ayo gage da dolanan, dolalane naning latar, ngalap padang gilar-gilar, nundung begog hangatikar. Artinya: terang-terang bulan, marilah lekas bermain, bermain di halaman, mengambil manfaat dari terang benderang, mengusir gelap yang lari terbirit-birit.

Adapun maksud dari tembang tersebut adalah agama Islam (bulan) telah datang memberi penerangan hidup, maka marilah segera orang menuntut penghidupan (dolanan, bermain) di bumi ini (latar,halaman) akan mengambil manfaat ilmu Agama Islam (padang gilar-gilar, terang-benderang) itu agar sesat kebodohan diri (begog, gelap) segera terusir. Saat ini tembang kinanthi masih ditampilkan di Masjid Sunan Giri terutama pada acara Hari Besar Islam Maulid Nabi Muhammad dan memperingati hari wafatnya Sunan Giri. Kesenian samroh atau yalil-yalil qasidah menampilkan vokal grup 12-15 penyanyi puteri melantunkan tembang kinanthi bernapaskan Islam dan iringi oleh alat musik tambur seruling harmonika dan ketipung Selain itu Permainan kedungdungan juga dimainkan pada Bulan Ramadhan yang dimulai dari malem selikur atau dua satu 
dan diakhiri mnjelang hari raya Idul Fitri. Adapun waktu pertunjukannya setelah shalat Ashar sampai mendekati Magrib sambil mengelilingi kota Gresik tujuannya meng ingatkan pada umat Islam bahwa menjalani puasa tinggal 10 hari lagi (Tim Penyusun Buku Gresik Dalam Perspektif Sejarah, 2003)

\section{9) Metode Permainan}

Untuk membangun suasana belajar yang menyenangkan, dinamis, dan penuh semangat Pesantren Giri mengadakan metode permainan dalam pembelajaran. Berbagai permainan yang menarik, mendidik dan berjiwa Islam seperti jelungan, jamuran, gendi gerit, jor, gula ganti, cublak-cublak suweng, ilir ilir dan sebagainya diciptakan oleh Sunan Giri (Hasyim, 1979). Permainan salah satu metode yang dapat merangsang dan melatih kognitif dan psikomotorik anak didik serta dapat meningkatkan motivasi dan prestasi belajar anak didik. Dengan permainan anak didik merasa senang dan gembira sehingga secara tidak langsung materi, isi dan pesan pelajaran tersampaikan.

Sunan Giri menciptakan permainan jelungan (jumpritan-Bahasa Jawa) sebagai media untuk mengajarkan tauhid Keesaan kepada Allah. Permainan jelungan dimainkan oleh sejumlah anak yang berperan sebagai buruan dan seorang anak sebagai pemburu. Para buruan akan selamat dari kejaran pemburu bila telah berpegang pada batang pohon atau tiang yang telah disepakati. Permainan ini melatih ketangkasan dan kewaspadaan siswa terhadap bahaya yang menyerangnya (dalam hal ini pemburu/iblis) dan selalu berpegang teguh kepada agama yang berdasarkan Ketuhanan Yang Maha Esa, maka manusia (buruan) itu akan selamat dari ajakan/ terkaman iblis yang dilambangkan dengan pemburu (Salam, 1960).

Dengan permainan dapat merangsang daya keterampilan dan ketangkasan santri dalam mengaktualisasikan diri, memiliki keberanian dan kepercayaan terhadap dirinya sendiri. Metode permainan dapat membentuk karakter akhlak santri. Seorang santri dalam bermain bersama orang lain tentu saja akan belajar cara bekerja sama, jujur, murah hati dan sportif. Selain itu, anak akan belajar mentaati peraturan dalam permainan yang telah ditentukan. Mereka pun dapat meningkatkan ketaatan pada sang Khalik dan kebersamaan dengan teman sepermainannya.

\section{Kesimpulan}

Pesantren Sunan Giri didirikan oleh Sunan Giri salah seorang walisanga yang memiliki peranan penting dalam penyebaran Islam di Tanah Jawa. Pesantren Giri tumbuh dan berkembang sebagai pusat pengembangan Islam dan mercusuar pusat pemerintahan Islam. Santrinya berdatangan dari berbagai daerah; Jawa, Maluku, Sulawesi, Sumbawa maupun Kalimantan. Dalam perkembangannya, Pesantren Giri menjadi masyarakat belajar yang berfungsi sebagai pusat dakwah dan pengembangan masyarakat, pusat latihan keterampilan dan bengkel kerja. pusat pendidikan dan latihan yang progresif dan produktif serta pusat informasi agent of culture aset sosial dan 
budaya menciptakan kemandirian dan kreatifitas bagi santri dalam berdakwah dan berkarya di masyarakat.

Pesantren Giri menerapkan metode pendidikan yang mengakulturasikan adat istiadat lokal dengan nilai-nilai Islam dengan metode sosiodarma pewayangan dan penampilan tembang macapat yang menghibur dan sarat makna. Pesantren Giri melaksanakan pembelajaran secara non klasikal sorogan, bandongan, dan wetonan yang diikuti oleh santri kalong atau santri yang mondok. Dalam melatih santri untuk komunikatif dan responsif terhadap berbagai problematika masyarakat, Pesantren Giri mengadakan metode diskusi, tanya jawab dan problem solving. Agar santri memiliki keterampilan dan keahlian dalam berbagai bidang kehidupan Pesantren Giri mengajarkan kemandirian dan metode pendidikan praktis belajar sambil bekerja pengamalan terhadap ilmu yang diperoleh. Pesantren Giri menyampaikan pesan dakwahnya dengan metode tembang-macapat atau melantunkan syair-syair Islami.

\section{BIBLIOGRAFI}

Amin, Darori. (2000). Islam dan kebudayaan Jawa. Yogyakarta: Gama Media, 83.Google Scholar

Bahri, Djamarah Syaiful, \& Djumarah, Aswan Zain. (2002). Strategi Belajar Mengajar Jakarta: Rineka Cipta. Google Scholar

De Graaf, Hermanus Johannes, \& Pigeaud, Th G. Th. (1985). Kerajaan-kerajaan Islam di Jawa: Peralihan dari Majapahit ke Mataram. Jakarta: Grafiti Pers. Google Scholar

Dhofier Zamakhsyari. (2011). Tradisi Pesantren. Jakarta: LP3S.

Erfan. Abu Fatoni Muhammad, tth., Sejarah Kehidupan Sunan Giri. Surabaya: CV. Bali.

Gani, Roeslan Abdul. (2012). Sejarah Sunan Drajat dalam Jaringan Masuknya Islam di Nusantara. Lamongan: Badan Perpustakaan Dan Arsip Daerah Kabupaten Lamongan. Google Scholar

Hasyim, Umar. (1979). Sunan Giri. Kudus: Menara Kudus. Google Scholar

Jalaludin. (1990). Kapita Selekta Pendidikan. Jakarta: Kalam Mulia.

Kasdi, Aminuddin. (2005). Kepurbakalaan Sunan Giri. Surabaya: Unesa University Press.

Lembaga Riset Islam Pesantren Luhur Malang dan Panitia Penelitian Dan Pemugaran Sunan Giri, 2014. (2014). Sejarah Perjuangan Dan Dakwah Islamiah Sunan Giri cetakan III. Malang: Pustaka Luhur. 
Mustakim, Mustakim. (2020). Konstruksi Pemimpin Atas Tradisi Giri Kedaton Sebagai Identitas Sosial Budaya Masyarakat Kabupaten Gresik. Universitas Muhammadiyah Malang. Google Scholar

Mustakin. (2005). Gresik dalam Perspektif Sejarah. Gresik: Dinas Pendidikan dan Kebudayaan.

Rahimsyah, Anandha Putri. (2013). Program Hipotetik Bimbingan Pribadi Sosial Melalui Teknik Role Playing Untuk Mengembangkan Perilaku Prososial Peserta Didik: Studi Deskriptif Terhadap Peserta Didik Kelas Atas Sd Laboratorium Percontohan UPI Bandung Tahun Ajaran 2013/2014. Universitas Pendidikan Indonesia. Google Scholar

Salam, Solichin. (1960). Sekitar Walisanga, Kudus: Menara Kudus. 1.

Saridjo, Marwan, Shaleh, Abd. Rachman, \& Syarif, Mustofa. (1979). Sejarah Pondok Pesantren di Indonesia. Dharma Bhakti. Google Scholar

Shaleh, Abdul Rachman. (2000). Pendidikan Agama dan Keagamaan: Visi, Misi, dan Aksi. Jakarta: Gemawindu Pancaperkasa. Google Scholar

Slamet, Ahmad, tth. Ma'rifat dan Wasiat Sunan Giri. Surabaya: Inti Jiwa Edisi 40.

Soekarman. (1990). Babad Gresik. Gresik: Radya Pustaka Surakarta SM-137. Google Scholar

Sono, Luwar. (2008). Macapat Gaya Gresik. Surabaya: Karunia.

Sudihartono, Yudi. (2020). Penerapan Quizizz Dalam Pelaksanaan Penilaian Pengetahuan Peserta Diklat Di Badan Pengembangan Sumber Daya Manusia Daerah Provinsi Sumatera Selatan. Jurnal Lentera Pendidikan Pusat Penelitian Lppm Um Metro, 5(1), 1-15. Google Scholar

Suis, Manto. (2004). Menelusuri Jejak Pesantren. Yogyakarta: Alief Press. Google Scholar

Syamlawi, Ichsan, Pudjosumedi, \& Mahbub. (1983). Keistimewaan masjid agung Demak. Saudara. Google Scholar

Syarifudin, Albitar Septian. (2020). Impelementasi pembelajaran daring untuk meningkatkan mutu pendidikan sebagai dampak diterapkannya social distancing. Jurnal Pendidikan Bahasa Dan Sastra Indonesia Metalingua, 5(1), 31-34. Google Scholar

Tim Penyusun Buku Gresik Dalam Perspektif Sejarah. (2003). Gresik Dalam Perspektif Sejarah. Gresik: Kepala Dinas Pariwisata Informasi dan Komunikasi Kabupaten Gresik. 
Novita Siswayanti

Wawancara dengan Mohamad Ma'arif Pengurus Masjid Sunan Giri Gresik, 1 April 2016.

Wawancara dengan Mukhtar Djamil Tokoh Agama Gresik, 3 April 2016.

Wawancara dengan Mustakim, Pemerhati Sejarah Gresik, 4 April 2016

Wawancara dengan Oemar Zainudin Budayawan Gresik, 5 April 2016

Widodo, Dukut Imam. (2004). Grissee Tempo Doeloe. Pemerintah Kabupaten Gresik. Google Scholar

Yudhi. (2011). Giri Raja dan Sunan Besar yang Terlupakan. Jakarta: Diva Press. Google Scholar

Zainuddin, Mukti, Nelwan, Alfa, Farhum, St Aisjah, Najamuddin, Najamuddin, Hajar, M. A. Ibnu, Kurnia, M., \& Sudirman, Sudirman. (2016). Pemetaan Zona Potensi Penangkapan Ikan Cakalang Periode April-Juni di Teluk Bone dengan Teknologi Remote Sensing. Jurnal Penelitian Perikanan Indonesia, 19(3), 167-173. Google Scholar

\section{Copyright holder:}

Novita Siswayanti (2021)

\section{First publication right:}

Syntax Idea

This article is licensed under:

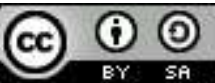

